\title{
Mechanical Properties of Food Gels
}

by

\author{
Nobuko NAKAHAMA \\ Japan Women's University \\ 2-8-1 Mejirodai, Bunkyoku, Tokyo 112
}

\section{食品ゲルのカ学的性質}

\author{
中 浜 信 子*
}

（1984年 5 月25日，京都）

多くの食品はゲル成分を含み, 食品の組織, 形態拉よびテクス チャーを形成している．食品ゲルは極めて多量の水分を含みなが ら形を保ち，それぞれ独特の力学的性質を示寸興味ある対象であ る. 寒天, でんぷん, ペクチン, マンナンなどの多糖類, 卵白, ゼラチン，大豆たん白，グルテンなどのたん白質はいずれる優れ たゲル形成能を持ち，多数のレオロジー的性質や，それに関連す る性状が調べられてきた。 これら食品ゲルの研究は，

1）それ自身，食品素材として重要であり，その性状を解明す ることに意義があるばかりでなく，

2）食品のテクスチャー改良のため有効であり，

3）わずかな添加物や調理加工の方法により，その性状を異に するので，それらに関する知見を得ることが望なれる. 更に，

4）かなり複雑な一般食品のレオロジー的性質を解明するため のモデル系の研究としても, 重要な意味を持つものであると考兄 る.

食品ゲルの力学的性質は，ゼリ一強度やテクスチャ一特性值な どにより客観評価がなされている場合が多いが，ここでは私ども の研究室で実験して来た研究を中心に, 食品ゲルのレオロジー的 研究の一端を紹介したい. 主として食品ゲルのレオロジー的測定 法, 静的粘弾性, 動的粘弾性, 大変形 - 破断特性などについて述 ベたいと思う。

\section{1. 食品ゲルのレオロジー的測定法}

食品のレオロジー的機器測定法として, Scott Blair ${ }^{11}$ は1)基礎 的方法，2)経験的方法，3)模擬的方法の三つの方法に分類できる としている. 経験的方法, 模擬的方法ははっきりとした力学的定

\footnotetext{
* 日本女子大学 $\bar{T} 112$ 東京都文京区目白台 $2-8-1$
}

数として定義づけられないが, 品質管理, 品質評価のための重要 な特性值を得る方法である．食品ゲルのレオロジー的性質を，で きるだけはっきりした力学的定数として求めるためには, 基礎的 方法が用いられている. クリープ測定, 応力緩和測定, 動的粘弾 性測定, 応力ーひずみ測定などが，しばしば用いられている．报 われる食品ゲルは主に弾性率 $10^{3} \sim 10^{7} \mathrm{dyn} / \mathrm{cm}^{2}$, 破断応力 $10^{3} \sim$ $10^{7} \mathrm{dyn} / \mathrm{cm}^{2}$ 程度のものである.ひずみの形式は伸張, 圧縮, ず りの変形方式がとられる. 小麦粉ドウやグルテンゲルなど, 水銀 浴に浮かせて測定する方法2)や, 測定中のゲルの離漿や, 乾燥, 自重による变形の防止の目的で, シリコンオイルや流動パラフィ ン浴中で測定する方法3),4)もとられる.

\section{2. 食品ゲルの静的粘弾性}

食品ゲルの粘弾性は10〜15\%のひずみ範囲で線形性が認められ るので，この範囲でクリープ測定や応力緩和測定がなされている. 寒天ゲル(5) 7), 卵白ゲル6) 8), 大豆たん白ゲル6),7), でんぷんゲ ル9)，ペクチンゲル(10),11)などのクリープ曲線が得られ，4要素ま たは 6 要素のフォークト型模型によって解析され, 粘弾性定数が 得られている.これらのゲルは濃度, 温度などにより, その挙動 もやや巽なるが，いずれる瞬閒弾性部のひずみが大である．寒天 ゲルでは定常流動のひずみが比較的大であり，でんぷんゲルでは 瞬間弾性部が主体であり, 大豆たん白ゲルでは遅延変形部が比較 的大である.

灾力緩和曲線も 4 要素から 7 要素のマックスウェル型模型によ り解析されている2),7),12) 20). 最長緩和時間を持つマックスウェ ル要素の弾性率によって, ゲルの主要な 3 次元網目構造のしなや かさが比較できると言われている15),19).

クリープ曲線から求めたフォークト型模型の粘弾性定数と, 応 
力緩和曲線から求めたマックスウェル型模型の粘弾性定数は, 同 数個の要素の模型と等価に，相互に換算できる，このことから同 一試料ゲルについて，同時に測定を行い，相互に換算し，互いに かなり一致することを確かめた7).

\section{3. 食品ゲルの動的粘弾性}

食品ゲルのレオロジー的測定の中で，短時間で測定でき，試料 に与える影響の少ない動的粘弾性測定は，極めて魅力的な測定方 法である，従来，測定装置がかなり高価であったことから，食品 ゲルへの利用は限定されていた．しかし，近年，食品ゲルのため の動的粘弾性測定装置が比較的安価汇試作・実用化され ${ }^{3), 4)}$, 動 的方法が食品ゲルの研究に利用されつつある.この装置は周波数 $2.0 \mathrm{~Hz}$, 振幅 $\pm 100 \mu \mathrm{m}$ と限定されているが, 值接動的粘弹性定数 $E^{\prime}$ 扔よび $E^{\prime \prime}$ を得るものである。寒天ゲル，卵白ゲル，大豆たん 白ゲルについて測定し，静的粘弾性と比䔩した ${ }^{20)}$. 短時間で測定 可能なことから，食品ゲルの温度変化や放置時間による影響，添 加物の影響 ${ }^{21)}$, 混合ゲル22)などについても研究されている.

寒天ゲルの動的弾性率の $10 〜 60^{\circ} \mathrm{C}$ の間の温度依存性を求め, 30 $\sim 40^{\circ} \mathrm{C}$ 極大を持つ比較的変化の少ない山型の挙動が得られてい $ろ^{23)}$. $50^{\circ} \mathrm{C}$ 以上になると, やや弾性率を減ずる。 これは寒天ゲル が本質的にはエントロピー弾性であるが，その弾性の由来する架 橋点が水素結合などの弱い結合であり，エントロピー的挙動が二 次結合の消滅により消されるためであると考劣られる。な拉，コ ンニャクマンナンのアルカリゲルについては, エントロピー的弾 性が認められている ${ }^{24), 25)}$.

\section{4. 食品ゲルの大変形・破断特性}

食品ゲルの大変形・破断現象についての理諭的解析は，まだ行 われているとは言えない，乙かし，食品ゲルとして大変形，破断 特性は重要な性質であり，古くからゼり一強度や侵入度といった 実用測定がなされて来た．破断現象は㥛めて確率的であり，形状 効果や体積効果に支配されることが知られている．寒天ゲルにつ いてクリープ破断の確率的試験を行い，平均破断応力に対し変動 率が $20 \%$ にぶことが認められた ${ }^{26)}$. 定速圧縮破断応力の変動率 は数\%であった。また，定速圧縮の破断応力・破断エネルギーは 圧縮速度の增大により著しく増大した．しかし，破断ひずみの変 化は少なかった27). 破断ひずみは寒天ゲルでは28〜35\%，卵白ゲ ル60\%，大豆たん白ゲルで70〜90\%で，それぞれ濃度や圧縮速度 で変動はあるが，各食品ゲルについて固有の数值を示している.

食品ゲルの弾性率, 破断応力などは, それぞれ濃度が增加する に従い増大する．弾性率の大さい寒天グルが破断応力は小さく， 弾性率の小さいゼラチンゲルが破断応力は大きい28)など，粘弾性 定数と破断特性を併せて示すと，実際のゲルのテクスチャ一の感 覚とよく対応している. 大変形・破断現象についての定量的な报 いが更に進めば，食品の製造加工・調理過程のレオロジー的品質 管理，品質評価も一層有効なものになると考学られる.

以上食品ゲルの静的粘弾性，動的粘弾性，破断特性などについ
て，実験結果の一部を紹介した．実際の食品はかなり複雑な分散 系のものも多く, 油滴の分散や気泡の分散 ${ }^{29)}$, 混合ゲル ${ }^{22)}$ の粘弾 性挙動，また添加物，pHの影響など，モデル系の実験の積み重ね から, 実際の食品のレオロジー特性を解明する手掛かりが得られ， 更にレオロジーの食品への有效な利用が可能になって行くことを 期待したい。

\section{文献}

1) G.W. Scott Blair : Adv. Food Res., 8, 1 (1958).

2）松本幸雄, 片山幸二, 米沢大造 : 日本レオロジー学会誌, 2, 63 (1974).

3) K. Nishinari and H. Horiuchi : Japan. J. Appl. Phys., 16, 1127 (1977).

4）西成勝好, 堀内久弥, 石田勝己, 池田勝則, 伊達宗宏, 深 田栄一：日食工誌，27，227 (1980).

5）中浜信子 : 家政誌, 17, 197 (1966).

6）桑畑美沙子，中浜信子：農化，49，129（1975）.

7）磯崎初恵，赤羽ひろ，中浜信子：農化，50，265 (1976).

8）中浜信子, 前田フミ子, 鯨井誠子：家政誌, 18，365(1967)

9）中浜信子, 山本誠子, 茂木美智子 : 家政誌,22, 302(1971).

10) E.L. Watson : J. Food Sci., 31, 373 (1966).

11）川端晶子, 沢山茂：農化, 50, 555 (1976).

12) K. Arakawa : Bull. Chem. Soc. Japan, 33, 1568 (1960).

13) K. Arakawa : Bull. Chem. Soc. Japan, 34, 1233 (1961).

14) K. Arakawa : Bull. Chem. Soc. Japan, 35, 309 (1962).

15) M. Watase and K. Arakawa : Bull. Chem. Soc. Japan, 40, 472 (1967).

16) M. Watase and K. Arakawa : Bull. Chem. Soc. Japan, 41, 1830 (1968).

17）渡瀬峰男：日食工誌, 20, 104 (1973).

18）渡瀬峰男, 荒川泓：日化誌，1，37（1971）。

19) Y. Sato and T. Nakayama : J. Texture Studies, 1, 309 (1970).

20）小林三智子, 赤羽ひろ, 中浜信子 : 家政誌, 32, 660(1981).

21) M. Watase and K. Nishinari : J. Texture Studies, 12, 427 (1981)

22) H. Moritaka, K. Nishinari and H. Horiuchi : J. Texture Studies, 11, 257 (1980).

23）名倉秀子, 赤羽ひろ, 中浜信子：日食工誌，31，339 (1984).

24）平井西夫：日化誌， 73，65（1952）.

25）渡瀬峰男：日食工誌，22，485（1975）.

26）上市康子，大村公仁子，赫羽ろ，中浜信子：家政誌， 31, 643 (1980).

27）大村公仁子, 赤羽ひろ, 中浜信子 : 家政誌， 29，22(1978).

28) H. Kimura, S. Moritaka and M. Misaki : J. Food Sci., 38, 668 (1973).

29）椎木靖彦，矢野俊正：第10回食品の物性に関するシンポジ ウム講演要旨集 (1983)。 